\title{
PRESCHOOL TEACHERS AND MUSICALLY GIFTED CHILDREN IN SLOVENE KINDERGARTENS
}

\author{
Jerneja Žnidaršič ${ }^{1}$, Barbara Sicherl Kafol ${ }^{2}$, Olga Denac ${ }^{3}$ \\ ${ }^{1}$ Department of Music, Faculty of Education, University of Maribor, Slovenia \\ ${ }^{2}$ Department of Primary Teachers Education, University of Ljubljana, Slovenia \\ ${ }^{3}$ Department of Preschool Education, Faculty of Education, University of Maribor, Slovenia \\ jerneja.znidarsic@um.si; barbara.sicherl@pef.uni-lj.si; olga.denac@um.si
}

Received: 25 May 2021

\begin{abstract}
The aim of the present study, which involved preschool teachers, was to explore the area of working with musically gifted children. In particular, we focused on the identification of musically gifted children and monitoring of their musical development, preschool teachers' competence for working with children, and evaluation of factors important for the development of musically gifted children. Research results showed that the majority of preschool teachers: were able to identify musically gifted children; rarely monitored and documented children's musical development systematically and did not acquire enough knowledge for working with musically gifted children during their formal and informal education. Among the important factors influencing the development of musically gifted children, preschool teachers pointed out motivation to work with musically gifted children, identification of musically gifted children, cooperation with music experts and parents, and implementation of additional musical activities.
\end{abstract}

Keywords: musically gifted children, preschool teachers, identification of musically gifted children, professional qualification

\section{Introduction}

In recent years, we have assumed a more systematic approach to the issue of identification and teaching of gifted children in Slovenia than in the past (Juriševič, 2012). Professional guidelines for modern- 
izing the concept of identification of gifted children, pupils, and secondary-school students and for working with them (2019), established at the national level, direct kindergartens and schools', towards identifying gifted children and pupils and ensuring learning conditions that favour their development.

Important directions for the identification of gifted children can already be found in the basic programme document for working with children. The principle of equal opportunities and recognition of differences among children set out in the Curriculum for Kindergartens $(1999,8)$, is implemented through the insurance of equal conditions for the development of every child, while considering individual differences in the development and in learning. The objectives in the Curriculum for Kindergartens $(1999,10)$ promote a balanced array of various areas and activities, which on one hand, enables a more in-depth focus in individual areas and on the other, a greater variety in all activity areas of preschool education. Monitoring the development of the gifted in the preschool period is of particular importance, as their learning is very intense and fast. In some children, musical giftedness can be detected at a very early stage. The Curriculum defines music as part of a broader activity area, i.e. the arts, which consists also of art, design, dance, theatre, and audiovisual activities. The objectives and examples of activities enable children to realise their creative potentials which are shown in their music exploration and learning.

Neuroscientists underline the importance of early recognition of a child's potential and the creation of connections between neurons with adequate stimulation (Bregant, 2012; Stadelmann, 2003). In this period, a child's attitude to learning is shaped, representing the motivational potential for the formation of a positive attitude to learning at any later point in their life (Dweck, 2006). The results of a study by Ruismäki and Tereska (2006) also point out the importance and influence of musical experience in early childhood on the attitude and musical achievements in adulthood.

The present paper addresses musically gifted children, from the perspective of preschool teachers. In the research presented, special

\footnotetext{
${ }^{1}$ Admission of children into kindergartens at the age of eleven months, and into compulsory school at the age of 6 .
} 
emphasis is placed on the nature of the identification of musically gifted children, the monitoring of their musical development, evaluation of the factors important for the development of musically gifted children, and the preschool teachers' beliefs regarding their competences for working with musically gifted children.

\section{Giftedness and talent}

Due to the complexity and the dynamics of phenomena, giftedness and talent are understood and used in various ways, through different conceptualizations of the terms. The evolution of ideas, described by Kaufman and Sternberg (2008, 72-78), is reflected in four sets of models. In domain-general models (Galton, 1869; Spearman, 1904; Terman, 1916), giftedness and talent were used almost interchangeably and general intelligence was the focal point of research interest. With domain-specific models (Carroll, 1993; Gardner, 1983; Thurstone, 1938) the notion of general intelligence was challenged with hierarchical psychometric definitions of intelligence, which led to understanding giftedness in relation to hierarchically related abilities. It was implied that individuals can be gifted in various areas, therefore it is necessary to encourage the progress of skill level in the specific domain. That notion evolved with systems models (Renzulli, 1978); Sternberg, 2003), where the importance of co-dependent psychological processes was considered. One of the well-known systems models was represented by Renzulli (1978), in The three-ring conceptions of giftedness, where giftedness is explained through main dimensions of human potential for creative productivity, namely, three clusters of traits: above average ability, creativity, and commitment task, that are interacting with "personality and environmental factors that give rise to the three rings" (Renzulli 2016, 67). The Renzulli (1978) theory was modified by Mönks (1992), who presented the Multifactor model of giftedness, where environmental factors (school, family, peers) were added. Considering various external factors that can interact with internal factors and produce gifted behaviour is consistent with developmental models (Feldhusen, 1998; Feldman, 1992; Tannebaum, 1986; Gagné, 1985). Gagné (2005) for example, proposed the differentiated model of gifted and talented, where he distinguishes between naturally acquired gifted- 
ness and trained talent. Giftedness is therefore a natural or innate potential in different aptitude domains (intellectual, creative, socio-affective, sensorimotor, and others). Various environmental and intrapersonal catalysts can exert positive or negative impact, while talent is acquired by systematic learning, training, and practice. Individuals then can develop the talent that is a demonstration of superior performance, associated with different specific fields, including music.

Taking into consideration briefly presented models, along with other, nothing less important one's such as Pfeiffer (2015); Piirto (2008); Subotnik, Olszewski-Kubilius, and Worell (2011), the Slovenian Professional guidelines for modernizing the concept of identification of gifted children, pupils, and secondary-school students and for working with them (2019) define giftedness as an outstandingly above average (exceptional) characteristics of individual on the field of intellect (general or specific), learning (general or specific), creativity (art, science...), talents (specific art fields: music, dance...), psychomotorical or sensorimotorical fields (body-movement, sports), and on the filed of social skills and self-regulation (motivation, feelings, metacognition).

\section{Musical giftedness and talent}

The diversity of conceptions and definitions of (musical) giftedness and talent ${ }^{2}$ is also present in the field of music. According to Nauck-Börner (1983), musical talent cannot be precisely defined. It is a complexity of certain human characteristics that are in direct or indirect connection with music, are expressed to different levels, and interconnect in different ways. In a more recent definition, Haroutounian (2009a) describes musical talent as the ability of a deep awareness of sounds, inner sensation of and manipulation with sounds and communication with others through personal interpretation.

All the attempts to define musical giftedness stem from one problem: how to determine in a child the levels of development of individual musical abilities and how to compare these levels with an average level of musical abilities in children. Another problem lies in the fact that

2 In the article, the terms 'musical giftedness' and 'musical talent' are used interchangeably, depending on the source. 
musical giftedness can assume a variety of expressions: e.g. composer, soloist, concert attendee, etc. Even though we know that someone is gifted, we still need criteria to justify such belief.

The long-lasting efforts to determine the essence of musical talent have resulted in three different points of view:

- The first one represents a series of additive tests to determine musical talent which is composed of a number of relatively independent individual abilities (to discriminate pitch, loudness, duration, timbre of the sound and tonal memory) that can be measured irrespectively of one another (Seashore et al., 1960);

- The second point of view defines musical talent as a holistic model. It is a complex basis to determine musical talent which, in this case, is not seen as a sum of individual abilities, but rather as a mutual, dialectical interaction of a whole of specific musical abilities (Michel, 1960);

- The third point of view has at its forefront a dynamic model developed by Roth (1980), where talent is perceived as a process and achievement that can be developed.

The dynamic model of talent represents the basis for a preschool music education that focuses on the connections between a child's genetics and learning. Similarly, Dai (2017) advocates the evolving complexity theory (ECT), pointing out the need to focus on the development of talents which is made possible by an open, dynamic system, able to change according to the challenges in the environment.

The contemporary developmental models of giftedness (Heller et al., 2005; Piirto, 2008) and musical giftedness/talent (McPherson and Williamon, 2006) are focused on the context of complex factors including innate dispositions, socio-cultural environment, as well as cognitive and non-cognitive personal characteristics.

\section{Identification of musically gifted children}

Polarisation between the gifted and non-gifted is particularly strong in music. Lack of certain musical abilities in a child detected by a teacher or parents usually leads to the conclusion that child is not musically talented. Consequently, such a child renounces musical activities not only within the education process but also outside school. 
Differences in talents, which are considerable in all areas of human activity, are particularly accentuated in music. However, people do not differ by either having or not having a certain quality. The differences are gradual. Sutherland (2012) points out that the use of classical evaluation of data gathered is not appropriate to identify musically gifted children. Instead, she proposes an alternative assessment model which also includes the participation of children and where the focus is on feedback as help in planning new learning experiences. Identification is an ongoing process in which certain gifts can be recognised earlier than others or sooner in one individual and later in another. In the preschool period, we are talking about developmental process diagnostics, which means that we intentionally and systematically observe and monitor a child's progress in line with the principles of formative monitoring (APA, 2017).

Piirto (2008) lists the following characteristics of musically gifted children: spontaneous response to rhythm and melody, pleasure in singing familiar and made-up songs, relative or absolute pitch, sense of tonality, ability to link tonal pitches to visual symbols, appreciation of the aesthetical structure of music, ability to distinguish between contrasting parts of a composition, expression of the wish to play a musical instrument, attention to musical stimuli. The main indicators of musicality in a preschool child are the ability to notice musical contents and emotional response to music. Nikolić et al. (2016) point out well-developed musical abilities and skills of children as another important attribute of musical talent, apart from motivation, encouraging environment, and the chance of education.

Identification of musically gifted children should take place in a pleasant environment and in a form of a game to avoid a child having the feeling of being assessed and constrained. The most appropriate method is the observation of children during various musical activities.

Once the teacher identifies a musically gifted child, they must provide the child with individualised learning challenges as well as create the necessary conditions for the child's active role and participation (Rutar, 2013). They must also stimulate the child's motivation in the area where the highest potential is shown. Similarly, the Professional guidelines for modernisation of the concept of identification of gifted 
children, pupils and secondary-school students and for working with them $(2019,67)$ state:

"For children demonstrating high potentials as well as for all children in kindergarten, the principle of individualisation and personalisation of play and learning as two basic educational activities must be respected."

In Slovene kindergartens and schools, musical talent is often seen as less important. As a general rule, the curricula provide for general music education but do not include the possibility to develop special musical talents (Kovačič and Črčinovič Rozman, 2014). In order to adapt educational work to a child's abilities and interests, a teacher must be motivated and competent also in the field of working with musically gifted children.

\section{Research}

The aim of the present study was to examine opinions and assessments of preschool teachers on identifying musically gifted preschool children.

To achieve this aim, the research will attempt to answer the following research questions:

- Whether preschool teachers in kindergartens can identify potentially musically gifted children, and what characteristics of musical development preschool teachers the most frequently looked for to identify musically gifted children?

- How often do preschool teachers monitor the musical development of children and what documentation strategies do they use to identify musically gifted children?

- Whether preschool teachers believe that they are qualified to work with musically gifted children; where did preschool teachers acquire the knowledge to work with musically gifted children and which areas preschool teachers wanted to improve their professional knowledge in?

- How do preschool teachers evaluate the importance of individual factors for the development of musically gifted children? 


\section{Methodology}

The descriptive research involved preschool teachers from Slovene kindergartens $(\mathrm{n}=1122)$, who carried out the learning process with children aged 3 to 6 years and were selected based on simple random sampling.

Preschool teacher filled in a questionnaire, and their responses were used for data collection. The questionnaire included close-type questions (dichotomous questions, questions with verbal and graduated answers). The questionnaire was created in accordance with the following measurement characteristics:

Validity was based on rational judgement by experts (counsellors for the art of the national Education Institute) of the test questionnaire's content and design, and on its probing use.

Reliability was assured with precise instructions, unambiguous, specific questions, and with the comparison of the answers to content-related questions.

Objectivity, in the phase of collecting data, was based on the use of an electronic survey, and in the phase of evaluation, on the understanding of the answers without subjective interventions.

Gathered data were processed with the SPSS 27 programme . Data are presented in tables with the indication of the absolute (f) and percentage frequencies ( $\mathrm{f} \%)$.

\section{Results}

The results of the study will be presented in the line of research questions.

Whether preschool teachers in kindergartens can identify potentially musically gifted children, and what characteristics of musical development preschool teachers the most frequently looked for to identify musically gifted children? The majority of preschool teachers ( $\mathrm{f}=998$, $\mathrm{f} \%=88.9 \%$ ) were able to identify the potentially musically gifted children in their groups. 
Table 1. Characteristics most frequently used by preschool teachers while identifying musically gifted children

\begin{tabular}{|c|c|c|c|c|c|c|}
\hline \multirow{2}{*}{$\begin{array}{l}\text { Characteristics of } \\
\text { musically gifted } \\
\text { children }\end{array}$} & \multicolumn{2}{|c|}{ Yes } & \multicolumn{2}{|c|}{ No } & \multicolumn{2}{|c|}{ Total } \\
\hline & $\mathrm{f}$ & $\mathrm{f} \%$ & $\mathrm{f}$ & $\mathrm{f} \%$ & $\mathrm{f}$ & $\mathrm{f} \%$ \\
\hline $\begin{array}{l}\text { Well-developed melodic } \\
\text { hearing. }\end{array}$ & 761 & 76.3 & 237 & 23.7 & 998 & 100 \\
\hline $\begin{array}{l}\text { Well-developed rhythmic } \\
\text { hearing. }\end{array}$ & 820 & 82.2 & 178 & 17.8 & 998 & 100 \\
\hline $\begin{array}{l}\text { Ability to quickly learn } \\
\text { the lyrics and the melody } \\
\text { of a song. }\end{array}$ & 426 & 42.7 & 572 & 57.3 & 998 & 100 \\
\hline $\begin{array}{l}\text { Lively interpretation of } \\
\text { children's songs. }\end{array}$ & 515 & 51.6 & 483 & 48.4 & 998 & 100 \\
\hline $\begin{array}{l}\text { Skilfulness when playing } \\
\text { an instrument. }\end{array}$ & 358 & 35.9 & 640 & 64.1 & 998 & 100 \\
\hline $\begin{array}{l}\text { Frequent movement } \\
\text { response to music. }\end{array}$ & 396 & 39.7 & 602 & 60.3 & 998 & 100 \\
\hline $\begin{array}{l}\text { Intensive experience of } \\
\text { music content. }\end{array}$ & 372 & 37.3 & 626 & 62.7 & 998 & 100 \\
\hline $\begin{array}{l}\text { Frequent spontaneous } \\
\text { instrumental creation. }\end{array}$ & 433 & 43.4 & 565 & 56.6 & 998 & 100 \\
\hline $\begin{array}{l}\text { Frequent spontaneous } \\
\text { vocal creation. }\end{array}$ & 464 & 46.5 & 534 & 53.5 & 998 & 100 \\
\hline $\begin{array}{l}\text { Intense exploration of the } \\
\text { sound environment. }\end{array}$ & 343 & 34.4 & 655 & 65.6 & 998 & 100 \\
\hline $\begin{array}{l}\text { Great interest in musical } \\
\text { activities. }\end{array}$ & 609 & 61.0 & 389 & 39.0 & 998 & 100 \\
\hline
\end{tabular}

The results (Table 1) show that the majority of preschool teachers were able to identify a musically gifted child by their level of development of rhythmic and melodic hearing, expression of interest in musical activities, and lively interpretation of children's songs. 
How often do preschool teachers monitor the musical development of children and what documentation strategies they use to identify musically gifted children?

Table 2. Frequency of the planned monitoring of children's musical development

\begin{tabular}{l|r|r}
\hline $\begin{array}{l}\text { Monitoring } \\
\text { frequency }\end{array}$ & f & \multicolumn{1}{c}{$\mathbf{f \%}$} \\
\hline Often & 102 & 9.1 \\
Seldom & 702 & 62.6 \\
Never & 318 & 28.3 \\
Total & 1122 & 100.0 \\
\hline
\end{tabular}

The Table 2 shows that the majority of preschool teachers seldom monitor the musical development of children in a planned manner.

Table 3. Documentation methods that were often or seldom used in monitoring children's musical development

\begin{tabular}{lrrrrrrr}
\hline \multirow{2}{*}{ Ways of documentation } & \multicolumn{2}{c}{ Yes } & \multicolumn{2}{c}{ No } & \multicolumn{2}{c}{ Total } \\
& $\mathrm{f}$ & $\mathrm{f} \%$ & $\mathrm{f}$ & $\mathrm{f} \%$ & $\mathrm{f}$ & $\mathrm{f} \%$ \\
\hline Daily records & 300 & 37.3 & 504 & 62.7 & 804 & 100 \\
Anecdotal records & 218 & 27.1 & 586 & 72.9 & 804 & 100 \\
Records of critical events & 196 & 21.9 & 628 & 78.1 & 804 & 100 \\
Monitoring paper & 218 & 27.1 & 586 & 72.9 & 804 & 100 \\
Other & 126 & 15.7 & 678 & 84.3 & 804 & 100 \\
\hline
\end{tabular}

Most preschool teachers used none of the above documentation methods. Some preschool teachers used several documentation methods, which is why the differences between individual documentation methods were not significant. Still, it is evident that more preschool teachers used daily records than anecdotal records or monitoring papers which, due to the predefined parameters, enable a more objective evaluation of the child's development. Fewer preschool teachers recorded 
only the critical events, whilst some of them used other documentation methods, such as video or audio recordings, or did not keep any special documentation at all.

Whether preschool teachers believe that they are qualified to work with musically gifted children; where did preschool teachers acquire the knowledge to work with musically gifted children and which areas preschool teachers wanted to improve their professional knowledge in? More than a half of teachers $(\mathrm{f}=624, \mathrm{f} \%=55.6 \%)$ estimated that they had enough knowledge for successful work with musically gifted children, somewhat less of them ( $\mathrm{f}=286, \mathrm{f} \%=25.5 \%)$ believed that their knowledge in this area was insufficient, whilst some of the preschool teachers $(\mathrm{f}=212, \mathrm{f} \%=18.9 \%$ ) were unable to judge.

Table 4. Ways of acquiring knowledge for working with musically gifted children

\begin{tabular}{|c|c|c|c|c|c|c|}
\hline \multirow{2}{*}{ Education } & \multicolumn{2}{|c|}{ Yes } & \multicolumn{2}{|c|}{ No } & \multicolumn{2}{|c|}{ Total } \\
\hline & $\mathrm{f}$ & $\mathrm{f} \%$ & $\mathrm{f}$ & $\mathrm{f} \%$ & $\mathrm{f}$ & $\mathrm{f} \%$ \\
\hline $\begin{array}{l}\text { Formal high school } \\
\text { education }\end{array}$ & 408 & 36.4 & 714 & 63.6 & 1122 & 100 \\
\hline $\begin{array}{l}\text { Formal faculty } \\
\text { education }\end{array}$ & 534 & 47.6 & 588 & 52.4 & 1122 & 100 \\
\hline $\begin{array}{l}\text { Formal education at } \\
\text { music school }\end{array}$ & 144 & 12.8 & 978 & 87.2 & 1122 & 100 \\
\hline Seminars, trainings & 396 & 35.3 & 726 & 64.7 & 1122 & 100 \\
\hline Own musical activity & 288 & 25.7 & 834 & 74.3 & 1122 & 100 \\
\hline $\begin{array}{l}\text { Independent study of } \\
\text { professional literature }\end{array}$ & 198 & 17.6 & 924 & 82.4 & 1122 & 100 \\
\hline Work experiences & 420 & 37.4 & 702 & 62.6 & 1122 & 100 \\
\hline
\end{tabular}

Most teachers believed they had not acquired adequate knowledge to work with musically gifted children in the course of their formal and informal education. Fewer participants claimed to have acquired the necessary knowledge within the framework of a formal faculty educa- 
tion, through work experiences, within the framework of formal high school education, and at seminars or professional training.

Table 5. Desired education areas of professional improvement of preschool teachers

\begin{tabular}{|c|c|c|c|c|c|c|}
\hline \multirow{2}{*}{ Education areas } & \multicolumn{2}{|c|}{ Yes } & \multicolumn{2}{|c|}{ No } & \multicolumn{2}{|c|}{ Total } \\
\hline & $\mathrm{f}$ & $\mathrm{f} \%$ & $\mathrm{f}$ & $\mathrm{f} \%$ & $\mathrm{f}$ & $\mathrm{f} \%$ \\
\hline $\begin{array}{l}\text { Improvement of } \\
\text { instrument playing } \\
\text { techniques }\end{array}$ & 474 & 42.2 & 648 & 57.8 & 1122 & 100.0 \\
\hline Leading choirs & 102 & 9.1 & 1020 & 90.9 & 1122 & 100.0 \\
\hline $\begin{array}{l}\text { Additional knowledge } \\
\text { about the musical } \\
\text { development of children }\end{array}$ & 492 & 43.9 & 630 & 56.1 & 1122 & 100.0 \\
\hline $\begin{array}{l}\text { Utilization of modern } \\
\text { music teaching methods }\end{array}$ & 444 & 39.6 & 678 & 60.4 & 1122 & 100.0 \\
\hline Other & 42 & 3.7 & 1080 & 96.3 & 1122 & 100.0 \\
\hline
\end{tabular}

Most teachers did not want additional training in the proposed areas. Less than half of the interviewed preschool teachers would like to acquire new knowledge in the field of musical development of children and to improve their instrument playing technique. A large percentage of teachers would like to improve their utilization of modern music teaching methods. The participants showed the least interest in additional knowledge about leading a choir. Some of the participants did not find any answers that would comply with their desires, so they expressed their opinion under the item 'Other'. They expressed that music was not their strongest field of expertise, which was why they did not focus so much on it and did not want to acquire any additional knowledge.

How do preschool teachers' evaluate the importance of individual factors for the development of musically gifted children? The importance of individual factors for the development of musically gifted children was evaluated by preschool teachers using a five-grade scale ( 1 - the least important, 5 - the most important). 
Table 6. Preschool teachers' evaluation of the importance of individual factors for the development of musically gifted children

\begin{tabular}{|c|c|c|c|c|c|c|c|}
\hline Factors & & 1 & 2 & 3 & 4 & 5 & Total \\
\hline \multirow{2}{*}{$\begin{array}{l}\text { Recognition } \\
\text { of potentially } \\
\text { musically gifted } \\
\text { children }\end{array}$} & $\mathrm{f}$ & 0 & 12 & 102 & 498 & 510 & 1122 \\
\hline & $\mathrm{f} \%$ & 0.0 & 1.1 & 9.1 & 44.4 & 45.4 & 100 \\
\hline \multirow[b]{2}{*}{$\begin{array}{l}\text { Cooperation } \\
\text { with parents }\end{array}$} & $\mathrm{f}$ & 6 & 18 & 138 & 528 & 432 & 1122 \\
\hline & $\mathrm{f} \%$ & 0.5 & 1.6 & 12.3 & 47.1 & 38.5 & 100 \\
\hline \multirow{2}{*}{$\begin{array}{l}\text { Cooperation } \\
\text { with experts } \\
\text { in the field of } \\
\text { music }\end{array}$} & $\mathrm{f}$ & 6 & 48 & 102 & 408 & 558 & 1122 \\
\hline & $\mathrm{f} \%$ & 0.5 & 4.3 & 9.1 & 36.4 & 49.7 & 100 \\
\hline \multirow{2}{*}{$\begin{array}{l}\text { Cooperation } \\
\text { with music } \\
\text { schools }\end{array}$} & $\mathrm{f}$ & 18 & 30 & 174 & 438 & 462 & 1122 \\
\hline & $\mathrm{f} \%$ & 1.6 & 2.7 & 15.5 & 39.0 & 41.2 & 100 \\
\hline \multirow{2}{*}{$\begin{array}{l}\text { Professional } \\
\text { education } \\
\text { and training } \\
\text { of preschool } \\
\text { teachers }\end{array}$} & $\mathrm{f}$ & 6 & 24 & 174 & 426 & 492 & 1122 \\
\hline & $\mathrm{f} \%$ & 0.5 & 2.1 & 15.5 & 38.0 & 43.9 & 100 \\
\hline \multirow{2}{*}{$\begin{array}{l}\text { Motivation } \\
\text { of preschool } \\
\text { teachers for } \\
\text { working with } \\
\text { musically gifted } \\
\text { children }\end{array}$} & $\mathrm{f}$ & 0 & 18 & 66 & 468 & 570 & 1122 \\
\hline & $\mathrm{f} \%$ & 0.0 & 1.6 & 5.9 & 41.7 & 50.8 & 100 \\
\hline \multirow{2}{*}{$\begin{array}{l}\text { Individualized } \\
\text { programmes for } \\
\text { musically gifted } \\
\text { children }\end{array}$} & $\mathrm{f}$ & 18 & 36 & 258 & 522 & 288 & 1122 \\
\hline & $\mathrm{f} \%$ & 1.6 & 3.2 & 23.0 & 46.5 & 25.7 & 100 \\
\hline \multirow{2}{*}{$\begin{array}{l}\text { Additional } \\
\text { activities in the } \\
\text { field of music }\end{array}$} & $\mathrm{f}$ & 12 & 18 & 204 & 540 & 348 & 1122 \\
\hline & $\mathrm{f} \%$ & 1.1 & 1.6 & 18.2 & 48.1 & 31.0 & 100 \\
\hline
\end{tabular}


As it is evident from the table, almost all of the indicated factors were evaluated as important or even as very important. Factors which achieved the highest percentages were the motivation of the teacher, cooperation with experts, recognition of musical giftedness, implementation of additional activities, cooperation with parents, and implementation of individualised programmes.

\section{Discussion}

Research results indicate that most preschool teachers identify potentially musically gifted children. The need for early identification of musical talents is underpinned by various research findings which show that the development of perfect pitch as well as of other musical abilities is connected to an early introduction of music education (Chin, 2003; Haroutounian, 2009b; Winner and Valentine, 2000). Furthermore, child prodigies express their potential musical talent as early as at the age of two (Haroutounian, 2009b; McPherson, 2016). A study by Kovačič (2015) carried out with a sample of 432 musically talented pupils in Slovenia also showed that deviation of musically gifted students from the average is already evident at 6 and does not increase considerably with age. While identifying potentially musically gifted children, preschool teachers most frequently use characteristics such as well-developed rhythmic, and melodic hearing; expressed interest in musical activities, and lively interpretation of children's songs. According to Borota and Gortan-Carlin (2016), a musically gifted child expresses great interest in all sound-related contents, has well-developed listening perception, and is active in various musical activities. Musically gifted children have their rhythmic and melodic hearing and other musical abilities developed above average already in the preschool period (Chin, 2003; Haroutounian, 2009b; Winner and Valentine, 2000). However, the process of development in young children is individualised; it is important to take this into consideration and judge musical talent with caution in order for our findings to be accurate and reliable (Rodriguez Garcia-Caro, 2013).

Furthermore, the present study shows that the majority of preschool teachers seldom monitor musical development and that the most frequently used documentation methods are daily records. For success- 
ful work with musically gifted children preschool teachers should engage more in systematic monitoring of children's musical development through various musical activities, such as singing, playing instruments, creating and listening to music, in which children demonstrate the level of their musical abilities (rhythmic and melodic hearing, capability of aesthetic interpretation, musical memory) and knowledge. This is in line with contemporary types of authentic expression of musical talent (Haroutounian, 2000; Renzulli and Delcourt, 2013; Zimmerman, 2004). Sutherland (2012) recommends taking notes of children's achievements regularly, pointing out structured anecdotal notes. Systematic monitoring with timely and analytical feedback on the learning status is important to steer the musical development of pupils (Colwell, 2002; Fautley, 2010) in particular, that of musically gifted pupils. According to the Concept of Identification of and Work with Gifted Children, Pupils and Secondary Students (2019), a preschool teacher should keep a child's portfolio, i.e. a document intended for monitoring and documenting a child's progress, from the age of three on, constantly supplementing it with anecdotal notes, observation protocols and other evidence of progress. Although more than half of preschool teachers report that they are qualified to work with musically gifted children, research results of the present study confirm that preschool teachers believe, that they have not acquired adequate knowledge to work with musically gifted children in the course of formal and informal education. Kukanja Gabrijelčič and Čotar Konrad (2016) believe that preschool teachers need systematic training to learn how to recognise the signs of high potential in children and respond to them. However, before that, they first need to be made aware of their own (subjective) theories on giftedness in the preschool period. Nieuwmeijer et al. $(2019,868)$ also point out the need for constant training of preschool teachers, particularly in music, specifically musical play: "Such training then should focus on how to facilitate musical play, how to identify young children's musical needs and on subsequent guidance of children's play to answer these needs". Therefore, more attention should be paid to formal ${ }^{3}$ and informal train-

${ }^{3}$ The enrollment conditions at the faculties that educate preschool educators in Slovenia do not include checking the development of the musical abilities of future educators. 
ing of Slovenian preschool teachers for quality work with musically gifted children. However, in Slovenia, there is a shortage of such training programmes (Kukanja Gabrijelčič, 2011), and those that exist only have low participation due to a lack of preschool teachers' interest. As the results of the present study confirm, most teachers did not express the desire for additional training. More content related to working with musically gifted children should therefore be included in programmes of formal preschool teacher training and the establishment of new study programmes should be considered in order to improve education at faculties that train future teachers, school counsellors, and other professional workers in schools.

Amongst the factors affecting the development of musically gifted children evaluated as important by preschool teachers, motivation of teacher and cooperation with experts achieved the highest percentages. According to Zimmerman (2004), teacher's motivation and professional knowledge are both of considerable importance for the creation of a stimulating learning environment with plenty of musical activities. A teacher motivated to work with musically gifted children will encourage free artistic expression and consider children's wishes, abilities and personal traits. They will also be aware of the importance of cooperating with external actors - experts and parents and will take part in professional training. Besides a motivated teacher and cooperation with music experts, a stimulating family environment needs to be pointed out. According to Olszewski-Kubilius (2018), a family should support and follow a gifted child through all stages of development. Witte et al. (2015) also believe that parents play a key role in the development of gifted children.

To summarize the results of the research about opinions and assessments of preschool teachers on identifying musically gifted preschool children, we can conclude that majority of preschool teachers:

- identify potentially musically gifted children based on well-developed rhythmic, and melodic hearing, and expressed interest in musical activities,

- seldom monitors and document musical development of children,

- report that they are qualified to work with musically gifted children, even though they have not acquired adequate knowledge to 
work with musically gifted children in the course of formal and informal education,

- does not express interest in additional professional improvement in proposed education areas,

- evaluates motivation of teachers, cooperation with experts, and recognition of potentially musically gifted children as most important factors affecting the development of musically gifted children.

The preschool period is the most appropriate time for discovering musically talented children (Gülşah, 2017). As stated by Jeremić (2013, 101):

“... teacher can influence the development of the musical talent by activating the capabilities which children bring along from their families and enabling them to develop according to their individual maximum. The problem is that teachers tend to just assign more work to gifted children, meaning that the difference is merely in the quantity, not the quality of work." (Jeremić, 2013, 101)

Authors Pramling Samuelsson et al. $(2009,133)$ attribute the important role of the teacher in teaching children, especially in the fields of art (music, dance, and poetry):

"Children are creative and masters of play, but in order to become aware of distinctions, variation and invariance of the phenomena of the arts, children must be challenged by the teacher in order to clarify and to develop their thoughts." (Pramling Samuelsson et al., 2009, 133)

Promoting the development of gifted children within the educational process is a complex process. In Slovenia, new ways of working with gifted children at the early stage of the education process need to be considered. We should not just focus on how to identify more gifted children within the system, but rather on how to transform the system itself (Lenz Taguchi, 2010; Ziegler, 2005) to create new opportunities for young children to express and develop their abilities. Both, Sutherland (2012) and Dweck (1999) believe that the modern theory of learning and new perspectives on learning and intelligence enables us to attribute the right value to all abilities and also to properly encourage and develop them. Similarly, Mijanović (2016) says that it is necessary to create an educational environment that will allow for adaptation, individualisation, or differentiation of objectives, activities, methods, 
means, and forms of teaching and learning according to gifted pupils' abilities and developmental characteristics.

Programmes for and expectations towards musically gifted children should differ from regular programmes in the quality of learning process, as a learning process which activates all children, while taking into account their individual particularities and abilities for creative work, is the most important means to promote the development of gifted children. Pangrčič and Blažič (2017) argue that the selective concept of teaching the gifted, in which the latter are separated from the rest of the population, have not yielded significant success in practice. They are in favour of an integration concept, with common education and appropriate differentiation within various activities. Such programme would include activities which would complement or upgrade the regular learning programme, instead of replacing it. Similarly, O'Brien and Guiney (2001) stress, that educational work with gifted children should take place in mainstream classes, with suitable differentiation, as education of gifted children should be as inclusive as possible.

\section{Conclusions}

Identification of musically gifted children in the preschool period is crucial. It is of great importance that children have the opportunity to experience enough quality musical activities sufficiently early to prevent the loss of their innate musical potential. In the future, we should therefore consider:

- a systematic introduction of enrichment activities for musically gifted children in the regular programme (the options to enroll a child in a music school or a choir are not enough),

- a greater focus on the promotion of artistic expression and creation in music,

- The use of exploration activities to stimulate and promote the development of musically gifted children,

- documenting the progress made by musically gifted children,

- continuous training in working with musically gifted children for preschool teachers and

- the involvement of experts in the field of music in both identifying and working with musically gifted preschool children. 
The educational process of preschool music education must be built on the basis of the acquisition of general musical knowledge which stimulates interest and a positive attitude towards musical activities. However, it must also offer a possibility for musically gifted children to develop special musical talents through different creative activities. The preschool and the early primary school periods are critical for musical development and missed opportunities at this stage cannot be recuperated at a comparable quality later on. Quality feedback about the current children's learning development status with guidelines for future work requires competent teachers who do not judge giftedness merely on the basis of their feeling, without adequate expert consideration. Therefore, experts in the field of music should be included to provide assistance in the process of implementation of the curriculum.

We believe that only interaction between family, school, cultural and broader environment can contribute to timely identification and monitoring of musically gifted children and quality work with them. In order to successfully implement the modernised concept in kindergartens, primary and secondary schools (Professional Guidelines for Modernizing the Concept of Identification of Gifted Children, Pupils and Secondary-school Students and for Working with them, 2019) in Slovenia, we will need systemic financial support for development work, professional education and training of professional workers and evaluation studies at the national level aimed at monitoring the effectiveness of the modernised concept.

\section{References}

APA (American Psychological Association, Center for Psychology in Schools and Education) (2017), Top 20 Principles from Psychology for preK-12 Creative, Talented, and Gifted Students' Teaching and Learning. Available at https:// www.apa.org/ed/schools/teaching-learning/top-principles-gifted.pdf [8 March 2019]

Borota, Bogdana and Gortan-Carlin, Paula Ivana (2016), "Kompetencije odgojitelja za prepoznavanje glazbeno nadarene djece", in: Jukić, Renata; Bogatić, Katarina; Gazibara, Senka; Pejaković, Sara; Simel, Sanja; Varga, Aniko N. and Campbell-Bar, Verity (eds.), Zbornik znanstvenih radova s Međunarodne znanstvene konferencije Globalne i lokalne perspektive pedagogije, Osijek: Sveučilište Josipa Jurja Strossmayera, Filozofski fakultet, pp. 335-345. 
Bregant, Tina (2012) “Razvoj, rast in zorenje možganov”, Horizons of Psychology, 21(2), pp. 51-60. http://dx.doi.org/10.20419/2012.21.363

Carroll, John B. (1993), Human Cognitive Abilities: A Survey of Factor-Analytic Studies, Cambridge: Cambridge University Press.

Chin, Cristina S. (2003), "The development of absolute pitch: A theory concerning the roles of music training at an early developmental age and individual cognitive style", Psychology of Music, 31(2), pp. 155-171. http://dx.doi.org/10 $.1177 / 0305735603031002292$

Colwell, Richard (2002), “Assessment's potential in music education”, in: Colwell, Richard and Richardson, Carol (eds.), The New Handbook on Research on Music Teaching and Learning, Reston, VA: MENC, pp. 1128-1158.

Concept of Identification of and Work with Gifted Children, Pupils and Secondary Students (2019), Ljubljana: Zavod Republike Slovenije. Available at: https:// www.zrss.si/zrss/wpcontent/uploads/202003-11-koncept- nad.pdf [9 May 2019]

Curriculum for Kindergartens (1999), Ljubljana: Ministrstvo za šolstvo in šport, Zavod Republike Slovenije za šolstvo.

Dai, Yun Dai (2017), "Envisioning a new foundation for gifted education: Evolving Complexity Theory (ECT) of talent development", Gifted Child Quarterly, 61(3), pp. 172-182. http://dx.doi.org/10.1177/0016986217701837

Dweck, Carol S. (1999), Self Theories: Their Role in Motivation, Personality and Development, Hove: Psychology Press.

Dweck, Carol S. (2006), Mindset: The New Psychology of Success, New York, NY: Random House.

Feldhusen, John F. (1998), “A conception of talent and talent development”, in: Friedman, Reva C. and Rogers, Karen B. (eds.), Talent in Context: Historical and Social Perspectives on Giftedness, Washington, DC: APA, pp. 193-211.

Feldman, David H. (1992), "Intelligences, symbol systems, skills, domains, and fields: A sketch of a developmental theory of intelligence", in: Roselli, H. C. and MacLauchlan, G. A. (eds.), Proceedings from the Edyth Bush Symposium on Intelligence: Theory into Practice, Blue Printing for the Future, Tampa: University of South Florida, pp. 37-43.

Fautley, Martin (2010), Assessment in Music Education Classroom, Oxford: Oxford University Press.

Gagné, Françoys (1985), "Giftedness and talent: Reexamining a reexamination of the definitions", Gifted Child Quarterly, 29(3), pp. 103-112.

Gagné, Françoys (2005), "From gifts to talents: The DMGT as a developmental model", in: Sternberg, Robert J. and Davidson, Janet E. (eds.), Conceptions of Giftedness ( $2^{\text {nd }}$ ed.), Cambridge, UK: Cambridge: Cambridge University Press, pp. 98-120.

Galton, Francis (1869), Hereditary Genius, London: Macmillan.

Gardner, Howard (1983), Frames of Mind: The Theory of Multiple Intelligences, New York: Basic Books. 
Gülşah, Saranli Adile (2017), "A different perspective to the early intervention applications during preschool period: Early enrichment for gifted children", Egitim ve Bilim, 42(190), pp. 343-359. http://dx.doi.org/0.15390/ EB.2017.7062

Haroutounian, Joanne (2009a), "Musical talent assessment”, in: Kerr, Barbara (ed.), Encyclopedia of Giftedness, Creativity and Talent, Thousand Oaks: SAGE Publications, pp. 613-617.

Haroutounian, Joanne (2009b), "Musicians”, in: Kerr, Barbara (ed.), Encyclopedia of Giftedness, Creativity and Talent, Thousand Oaks: SAGE Publications, pp. 619-622.

Haroutounian, Joanne (2000), "MusicLink: Nurturing talent and recognizing achievement", Arts Education Policy Review, 101(6), pp. 12-20.

Heller, Kurt. A.; Perleth, Christoph and Tock Keng Lim (2005), "The Munich model of giftedness designed to identify and promote gifted students", in: Sternberg, Robert J. and Davidson, Janet E. (eds.), Conceptions of Giftedness ( $2^{\text {nd }}$ ed.), Cambridge: Cambridge University Press, pp. 147-170.

Jeremić, Biljana (2013), "Recognition and support program for children talented for music at junior age of school children", Metodički obzori, 8(2), No. 18, pp. 97-109.

Juriševič, Mojca (2012), Nadarjeni učenci v slovenski šoli, Ljubljana: Pedagoška fakulteta Univerze v Ljubljani.

Kaufman, Scott Barry and Sternberg, Robert J. (2008), "Conceptions of giftedness", in: Pfeiffer, Steven (ed.), Handbook of Giftedness in Children: Psychoeducational Theory, Research, and Best Practices, New York: Springer, pp. 71-91.

Kovačič, Bojan and Črčinovič Rozman, Janja (2014), "Musically talented pupils in Slovene elementary schools: Gender and age differences in the area of musical abilities", Croatian Journal of Education, 16 (4), pp. 1093-1118.

Kovačič, Bojan (2015), "Značilnosti glasbeno talentiranih učencev na razredni stopnji osnovne šole”, PhD diss., Ljubljana: Pedagoška fakulteta Univerze v Ljubljani.

Kukanja Gabrijelčič, Mojca (2011), "Pravičnost in enakost ali nadarjen v 'družbi za vse", in: Borota, Bogdana; Cotič, Majda; Hozjan, Dejan and Zenja Ljubov (eds.), Social Cohesion in Education, Horlivka State Pedagogical Institute for Foreign Languages, pp. 305-318.

Kukanja Gabrijelčič, Mojca and Čotar Konrad, M. (2016), "Izzivi in težave na področju odkrivanja in dela z mlajšimi nadarjenimi otroki”, in: Željeznov Seničar, Maruška (ed.), Nadarjeni in talentirani predšolski otrok, Ljubljana: Mib, pp. 28-38.

Lenz Taguchi, Hillevi (2010), "Rethinking pedagogical practices in early childhood education: A multidimensional approach to learning and inclusion", in: Yelland, Nicola (ed.), Contemporary Perspectives on Early Childhood Education, London: Open University Press, pp.14-32. 
McPherson, Gary and Williamon, Aaron A. (2006), "Giftedness and talent", in: McPherson, Gary (ed.), The Child as Musician. A Handbook of Musical Development, New York: Oxford University Press, pp. 239-256.

McPherson, Gary (2016), Musical Prodigies, New York: Oxford University Press.

Michel, Paul (1960), Über musikalische Fähigkeiten und Fertigkeiten. Ein Beitrag zur Musikpsychologie, Leipzig: Breitkopf \& Härtel Musikverlag.

Mijanović, Nikola (2016), "Personalised instruction in function of the development of gifted students", Pedagoška obzorja, 31(3/4), pp. 38-54.

Mönks, Franz J. (1992), "Development of gifted children: The issue of identification and programming", in: Mönks, Franz J. and Peters, W. (eds.), Talent for the Future: Social and Personality Development of Gifted, Proceedings of the Ninth World Conference on Gifted and Talented Children, Assen, The Netherlands: Van Gorcum, pp. 191-202.

Nauck-Börner, Christa (1983), "Musikalische Begabung", in: Kraemer, RudolfDieter and Schmidt-Brunner, Wolfgang (eds.), Musikpsychologische Forschung und Musikunterricht, Mainz: Schott, pp. 15-36.

Nieuwmeijer, Christiane; Marshall, Nigel and Van Oers, Bert (2019), "Dutch early years classroom teachers facilitating and guiding musical play: Problems and opportunities", European Early Childhood Education Research Journal, 27(6), pp. 860-871. http://dx.doi.org/10.1080/1350293X.2019.1678926

Nikolić, Igor; Blažič, Marjan and Kodela, Slobodan (2016), "Temeljne glasbene sposobnosti učencev kot dejavnik prepoznavanja glasbenega talenta", Pedagoška obzorja: časopis za didaktiko in metodiko, 31(3/4), pp. 3-20.

O'Brien, Tim and Guiney, Dennis (2001), Differentiation in Teaching and Learning: Principles and Practices, London: Bloomsbury.

Olszewski-Kubilius, Paula (2018), "The role of the family in talent development", in: Pfeiffer, Steven I. (ed.), Handbook of Giftedness in Children: Psychoeducational Theory, Research, and Best Practice, New York: Springer, pp. 129-147.

Pangrčič, Polonca, and Blažič, Marjan (2017), "Participatory individualised programmes for gifted students”, Didactica Slovenica, Pedagoška obzorja, 32(1), pp. 91-110.

Pfeiffer, Steven (2015), "Tripartite model of giftedness and best practices in gifted assessment", Revista de Education, 368, pp. 61-87. http://dx.doi.or$\mathrm{g} / 10.4438 / 1988-592 X-R E-2015-368-293$

Piirto, Jane (2008), "Giftedness in nonacademic domains", in: Pfeiffer, Steven I. (ed.), Handbook of Giftedness in Children: Psychoeducational Theory, Research, and Best Practice, New York: Springer, pp. 17-198.

Pramling Samuelsson, Ingrid; Carlsson, Maj Asplund; Olsson, Bengt; Pramling, Niklas and Wallerstedt, Cecilia (2009), "The art of teaching children the arts: Music, dance and poetry with children aged 2-8 years old", International Journal of Early Years Education, 17(2), pp. 119-135. http://dx.doi. org/10.1080/09669760902982323 
Professional Guidelines for Modernizing the Concept of Identification of Gifted Children, Pupils and Secondary-school Students and for Working with them (2019), Ljubljana: Zavod Republike Slovenije za šolstvo. Available at: https:// www.zrss.si/pdf/strokovna_izhodisca_nadarjeni.pdf [9 May 2019]

Renzulli, Joseph S. (1978), "What makes giftedness? Reexamining a definition", Phi Delta Kappan, 60, pp. 180-184.

Renzulli, Joseph S. (2016), "The three-ring conception of giftedness: A developmental model for promoting creative productivity", in: Reis, Sally (ed.), Reflections on Gifted Education: Critical Works by Joseph S. Renzulli and Colleagues, Prufrock Press, pp. 55-90.

Renzulli, Joseph S. and Delcourt, Marcia A. B. (2013), "Gifted behaviors versus gifted individuals", in: Callahan, Carolyn M. and Hertberg-Davis, Holly L. (eds.), Fundamentals of Gifted Education: Considering Multiple Perspectives, Routledge/Taylor \& Francis Group, pp. 36-48.

Rodriguez Garcia-Caro, José I. (2013), Opinion of the European Economic and Social Committee on 'Unleashing the potential of children and young people with high intellectual abilities in the European Union', Brussels: European Economic and Social Committee. Available at https:// https://eur-lex.europa. eu/LexUriServ [22 March 2020]

Roth, Heinrich (1980), Begabung und Lernen, Stuttgart: Klett-Cotta.

Ruismäki, Heikki and Tereska, Tarja (2006), "Early childhood musical experiences: Contributing to pre-service elementary teachers self-concept in music and success in music education (during student age)", European Early Childhood Education Research Journal, 14(1), pp. 113-130. http://dx.doi. org/10.1080/13502930685209841

Rutar, Sonja (2013), Poti do participacije otrok v vzgoji, Koper: Annales. http:// dx.doi.org/10.1080/13502930685209841

Seashore, Carl E.; Saetveit, Joseph Gehard and Lewis, Don (1960), The Seashore Measures of Musical Talents, New York: Psychological Corporation.

Spearman, Charles (1904), "General intelligence, objectively determined and measured”, American Journal of Psychology, 15(2), pp. 201-293.

Stadelmann, Willi (2003), Frühe Förderung und lebensbegleitendes Lernen im Lichte neuropsychologischer Erkenntnisse, lecture at the OECD regional seminar for German-speaking countries from September 29 to October 2, 2003 in Vienna. Available at http://talentstudio.ch/PDF/05-Stadelmann_FrueheFoerderung.pdf [13 March 2019]

Sternberg, Robert J. (2003), Wisdom, Intelligence, and Creativity, Synthesized, New York: Cambridge University Press.

Subotnik, Renata F.; Olszewski-Kubilius, Paula and Worrell, Frank C. (2011), "Rethinking giftedness and gifted education: A proposed direction forward based on psychological science", Psychological Science in the Public Interest, 12, pp. 3-54. http://dx.doi.org/10.1177/1529100611418056 
Sutherland, Margaret (2012), Gifted \& Talented in the Early Years: Practical Activities for Children aged 3 to 6 ( $2^{\text {nd }}$ ed.), London: SAGE Publications.

Tannenbaum, A. J. (1986). "Giftedness: A psychosocial approach”, in: Sternberg, Robert J. and Davidson, Janet E. (eds.), Conceptions of Giftedness, Cambridge University Press.

Terman, Lewis M. (1916), The Measurement of Intelligence, Boston: Houghton Mifflin.

Thurstone, Luis L. (1938), Primary Mental Abilities, Chicago: University of Chicago Press, pp. 21-52.

Winner, Aaron and Valentine, Elizabeth (2000), "Quantity and quality of musical practice as predictors of performance quality”, British Journal of Psychology, 91, pp. 353-376. http://dx.doi.org/10.1348/000712600161871

Witte, Amanda L.; Kiewra, Kenneth A.; Kasson, Sarah and Perry, Kyle R. (2015), "Parenting talent: A qualitative investigation of the roles parents play in talent development", Roeper Review Journal on Gifted Education, 37 (2), pp. 84-96. http://dx.doi.org/10.1080/02783193.2015.1008091

Ziegler, Albert (2005), “The Actiotope Model of giftedness", in: Sternberg, Robert J. and Davidson, Janet E. (eds.), Conceptions of Giftedness ( $2^{\text {nd }}$ ed.), Cambridge: Cambridge University Press, pp. 411-436.

Zimmerman, Enid (2004), Artistically and Musically Talented Students, United States: Corwin Press and the National Association for Gifted Children. 


\title{
ODGOJITELJI I GLAZBENO NADARENA DJECA U SLOVENSKIM VRTIĆIMA
}

\author{
Jerneja Žnidaršič, Barbara Sicherl Kafol, Olga Denac
}

Cilj ovog istraživanja, koje je uključivalo odgojitelje u vrtiću, bio je istražiti područje rada s glazbeno nadarenom djecom. Posebno smo se usredotočili na otkrivanje glazbeno nadarene djece i praćenje njihovog glazbenog napretka, kompetencije odgojitelja za rad s djecom i procjenom čimbenika važnih za razvoj glazbeno nadarene djece. Rezultati istraživanja pokazali su da je većina odgojitelja: uspjela otkriti glazbeno nadarenu djecu; rijetko su sustavno pratili $i$ dokumentiraliglazbeni napredakdjece inisu stekli dovoljno znanja za rads glazbeno nadarenom djecom tijekom svog formalnog $i$ neformalnog obrazovanja. Među važnim čimbenicima koji utječu na razvoj glazbeno nadarene djece odgojitelji su istaknuli motivaciju za rad s glazbeno nadarenom djecom, otkrivanje glazbeno nadarene djece, suradnju s glazbenim stručnjacima i roditeljima te provedbu dodatnih glazbenih aktivnosti.

Ključne rijječi: glazbeno nadarena djeca, odgojitelji, otkrivanje glazbeno nadarene djece, stručne kvalifikacije 